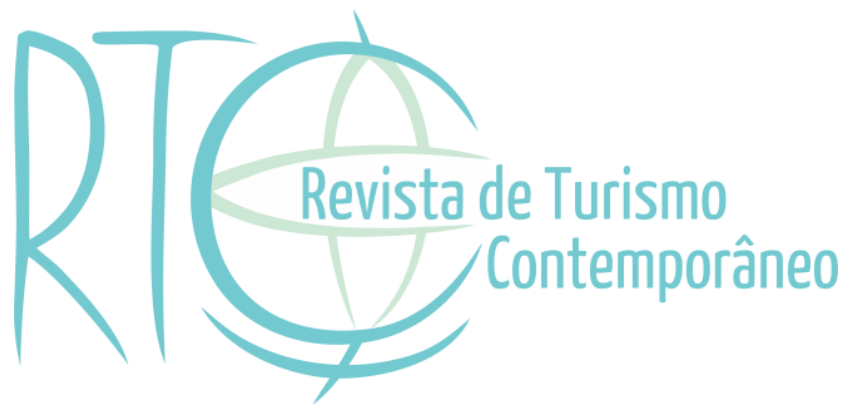

\title{
Creative economy, cinema and tourism: a study about the movie "Os Xeretas" in the city of Castro/ Paraná - Brazil
}

Economia criativa, cinema e turismo: um estudo sobre os filmes "OS Xeretas" na cidade de Castro/Paraná - Brasil

Débora Gonçalves Alencar

Master student of Turism by the University Federal of Paraná - UFPR, Curitiba/PR, Brazil E-mail: deborag.alencar@gmail.com

Marina Lima dos Santos

Master student of Turism by the University Federal of Paraná - UFPR, Curitiba/PR, BrazilEmail: slimamarina@gmail.com

Rodrigo Guissoni

Master student of Turism by the University Federal of Paraná - UFPR, Curitiba/PR, Brazil E-mail: guissonirodrigo@gmail.com

Article received on: 05-05-2020

Article approved on: 09-29-2020 


\section{ABSTRACT}

The sectors that correspond to the creative industries, such as, for example, the audiovisual contribute to various social, and cultural sectors in the destination. This paper presents the benefits that an activity such as film production can provide through the context of the creative economy, and those sectors related to the local image, communication with the market, can transform a place through the cinema (such as cinematographic production), that besides to providing new features for the locality, to serve as an example or model to be followed by other destinations. Thus, this article has a qualitative, and descriptive approach. To exemplify the performance attributed to this type of creative (cinematographic) production, this research presents the film "Os Xeretas" (2001) filmed in the city of Castro, state of Paraná - Brazil. After this film, elements related to economic, social, cultural, and tourist aspects were observed. As a result, during, and soon after production, opportunities were identified for the city, such as encouraging local development, through the involvement of people, products, and creative environments understood as aspects favorable to the promotion of tourism, as well as, the encouragement, and access of the population to cultural means through workshops, courses, and presentations. However, it is noteworthy that almost twenty years after this production, actions related to the creative economy have become obsolete, and have lost the status, and "luster" that they held in the past.

Keywords: Creative Industry. Cinema. Tourism. Local Development. Paraná - Brazil.

\section{RESUMO}

Os setores que correspondem às indústrias criativas, como o audiovisual, por exemplo, contribuem com vários setores sociais e culturais em um destino. Este artigo apresenta os benefícios que uma atividade, como a produção cinematográfica, promove através da economia criativa aos setores relacionados com a imagem local, comunicação com o mercado, e transformam um local por intermédio do cinema (como produção cinematográfica), além de fornecer novos recursos para a localidade, servir como exemplo ou modelo a ser seguido por outros destinos. Este artigo tem uma abordagem qualitativa e descritiva. Para exemplificar a performance atribuída a esse tipo de produção criativa (cinematográfica) esta pesquisa apresenta o filme "Os Xeretas" (2001) filmado na cidade de Castro, estado do Paraná - Brasil. Após esse filme, observou-se elementos relacionados aos aspectos econômicos, sociais, culturais e turísticos. Como resultado, durante e logo após a produção, houve a identificação de oportunidades para a cidade, como o incentivo ao desenvolvimento local, por meio do envolvimento entre pessoas, produtos e ambientes criativos entendidos como aspectos favoráveis à promoção do turismo, bem como, o incentivo e acesso da população aos meios culturais através de oficinas, curso e apresentações. Porém, notou-se que passados quase vinte anos após essa produção, as ações relacionadas a economia criativa tornaram-se obsoletas e perderam o status e o "brilho" que detinham no passado.

Palavras-chave: Indústria Criativa. Cinema. Turismo. Desenvolvimento Local. Paraná Brasil. 


\section{INTRODUCTION}

If on the one hand the relationship between tourism, and creativity can be understood by the new needs in the reinvention of economies; these are aimed at leisure, consumption, and trends of urban regeneration. As a strategy of urban regeneration emerges the use of creativity, in the role of creative industries, which make use of human talent in their activities (Gonçalves, 2008). On the other hand, such actions require constant maintenance, and adaptations to maintain their functioning, and achieve all the benefits in the short, medium, and long-term.

Thus, among the range of creative industries proposed in the literature, this work evidenced the audiovisual industry, specifically cinema. Therefore, when it comes to audiovisual as a creative industry, which is part of the economy of a given place, reference is also made to the concept of a creative economy. In this way, the creative economy:

[...] it deals with goods, and services based on texts, symbols, and images, and refers to the set of activities based on creativity, talent or individual skill, whose products incorporate the intellectual property, and embrace from traditional crafts to the complex production chains of cultural industries [...] (Miguez, 2007, p. 96).

According to Silveira and Baptista (2017), it is possible to understand cinema as a creative differential that reinforces new places, and arouses interest through its images, so that when a city is the setting for a film there is increased visibility, and the possibility of boosting the development of new economies caused by the audiovisual, and tourism sector.

However, this research does not aim to present the theme of cinematographic tourism, as such, but how the creative industry can provide benefits to all sectors including tourism. Thus, when considering the interface, the film industry, what would be the contribution of the audiovisual creative industry to a city? What are the characteristics of the dynamics of film activities from the perspective of the creative economy?

To answer these questions direct us to a context beyond the knowledge of the elements of the creative industry, and how it communicates with a city, and with activities that coexist simultaneously in the same environment. In Brazil, cultural sectors, often have difficulties not only in terms of incentives but also due to a lack of engagement with the local community, that is, due to the lack of an explanation about the benefits of having access to any type of service cultural. In this scenario, the research aims to understand cinema as an element that attributes aspects to a place, in this case, the city of Castro-PR, Brazil, that was the setting of the movie 
"Os Xeretas"1 (2001) (Justos, 2015). Although the film was shot in 2001, it was possible to perceive the role of the creative economy in this city, as we will see later, as well as the local transformation, social integration, and contemporary outcomes. For this purpose, we used the perspective of territory in constant geographical social construction, which in the cultural aspect is related to space lived, and with the appropriation of meanings, in the economic perspective as a source of resources, and capital relationship (Emmendofer \& Ashton, 2014, pp. 2-3).

In this way, it is considered that creativity shapes new products for tourism to adapt to the current paradigms of travel, in which the interaction between entertainment sectors, such as cinema, theater, music, gastronomy, among others, allows the market to relate beyond the commercial environment, involving social and cultural aspects that, in parallel with the constant convergence of the media, cause changes in the human, and experiential aspect of tourism. Thus, they stimulate innovation, and the study of new possibilities that favor trends, and typologies in tourism (Rocha \& Brusadin, 2012; Campo, Fraiz Brea, \& González, 2013; 2014; Costa, Brandão, \& Vieira, 2018).

This paper begins with the literature review on the theme of creativity associated with the tourist context along with the description of the object of study as well as the field research, to elucidate the context to the reader, while the second part refers to the methodological procedures adopted for research, and finally, analysis with results, and perceptions.

\section{THEORETICAL BACKGROUND}

The cultural tourism is in a continuous process of transformation since there are influences of new trends expanded by information technologies that configure demand and expand supply. Thus, the relationship between tourism and its social, and economic implications of culture contributes and allows the construction of new knowledge about cultural tourism (Campo et al. 2013; 2014; Tomazzoni, 2008). On cultural tourism, Richards (2009) points out how variable the concept is because it depends on the motivations of the trip being essentially cultural, as well as the activities developed during the trip. Moreover, in the present times the search for culture has gone from "high" culture to popular culture: if tourists once demanded "particularly museums, monuments, and art festivals", nowadays this cultural demand has also been searching for "elements of "popular" culture, such as gastronomy,

\footnotetext{
1 "Xereta", in the singular, is a term used in Brazil. According to a definition in the Michaelis Brazilian dictionary (2020) refers to people who intrude in private matters in an inconvenient way. In free translation from Portuguese to English it would be "a nosy person".
} 
cinema, sports, and television" (Richards, 2009, p. 1). In other words, the culture of a place, whether attributed to external factors such as cinema, and the other arts or built over time by traditions, satisfies both its local population, and its visitors.

Therewith, Richards (2011), points out the tourism is an important factor in economic development in areas related to culture, and creativity. This is due to the practice of tourism involving people, products, and environments said as creative, that is, tourism is a creative industry, in the role of so-called creative tourism. This can be considered as an alternative to the mass forms of cultural tourism, meeting the new demands of consumption, centered on experiences, and the appreciation of the culture of each place.

These elements make up the so-called creative industry, as a category of the creative economy that encourages the innovation of current business models, organizational processes, and ordering those benefit sectors, and economic, and social agents, configuring itself as a strategy for sustainable territorial development. (Bendassolli, Wood, Kirschbaum, Pina, \& Cunha, 2009; Emmendoerfer \& Ashton, 2014). To Tomazzoni (2012), among the interdisciplinary relations of tourism, the economy contributes to the development of tourism activity through new theories, and strategy models aimed at social capital promoted by innovation, and expansion humanistic, cultural, and economic in an integrated way, for this, relations of reciprocity between companies, community, governments, and research institutions are necessary. Social capital is understood as any form of knowledge acquisition, access to culture, arts, and any other form of cognitive enrichment.

In light of authors like as Santos, Alencar and Neves (2018) it was observed that the performance of the creative economy through the audiovisual sectors as an element of communication promotes relations between the city, companies, and managers producing benefits such as job creation that encompasses creativity, and competitiveness about tourism through a combination of multiple factors, and tangible, and intangible resources.

On the study of the creative economy, and tourism, Emmendoerfer and Ashton (2014, p. 20) bring the conception of creative territories, like as being these " multiscale spaces, built from a formative process adopted by a group of people in time", spaces that promote creative, and dynamic actions, thus managing to offer cultural products. In this perspective, the authors cited above point out that every city can be constituted by a creative territory, but not all creative territory is a creative city. To that end, it is necessary to understand the unique traits of each place to project it in some economic-cultural sector. 


\subsection{Creative sectors and tourism}

Nowadays, creativity has been seen as a strategic instrument of urban (re)conversion, given the changes in paradigms of economic growth, that is, to accompany these rapid transformations of society in the social, economic, and cultural spheres, professions, and cities, needed to reinvent themselves through the production modes of these spaces. Thus, in the face of new problems, or problems that no longer respond to conventional solutions, the use of the word creativity was established as a strategic instrument for the knowledge economy, whose need is to be ahead of these new obstacles. In this way, the use of creativity as the new paradigm of the world becomes an instrument for those destinations who want to be competitive (García Suárez, \& Pulido Fernández, 2015).

In this context, the creativity emerged like as a concept of industries or creative sectors, originated in Australia in the early 1990s, and resonated in the world when it came to be used by the UK government in 1994 for a mapping of the so-called activities as creative in that country. Afterward, this repercussion caused economic changes in some industrialized countries that began to focus on certain activities that used human knowledge, and talent, such as architecture, the arts, and antique market, handicrafts, design, fashion, cinema, interactive software; designated for leisure, music, performing arts, the publishing industry, radio, TV, museums, and galleries, as well as activities related to cultural traditions (Reis, 2008; Furtado, 2015).

However, Landry (2011), points out that growing development, definition, and conceptualization of these industries is not only the product of an economic crisis or public policies, but these industries or sectors also emerged due to the so-called cultural turn, a period that brought with it the beginning of a process of transformation of latent social, and cultural values (Bendassolli et al., 2009) ${ }^{2}$.

From this perspective, the creative industries began to have different concepts or classifications. The United Nations Conference on Trade and Development (UNCTAD) classifies the creative industries into four groups: heritage, arts, media, and functional creations.

2 Bendassolli et al. (2009), points out that the culture upset can be understood based on the discussion of terms present in the literature that refers to this in the last ten years and deal with a "mutation of values" social and economic of the so-called postmodern society. In practical terms, this mutation deals with the emergence of new economic relations produced from the use of culture. These authors show that members of postmodern society are more interested in the supply of intellectual needs and quality of life (among others) and are also part of the socalled knowledge economy, where capital goes beyond the traditional sense and is also intellectual. These social and economic changes led to the emergence of several terms and one of them is the creative economy (mentioned earlier in this work). 
Hartley (2005) characterizes a creative industry like the one where the product is the result of creative individuals and can be divided into advertising, architecture, design, interactive software, film and TV, music, publications, performing arts.

In Brazil, the concept was discussed by the Federation of Industries of Rio de Janeiro, also known as FIRJAN system, in its mapping of creative industries in Brazil from 2015 to 2019, divided segmentation into four distinct lines: Consumption (Design, Architecture, Fashion, and Advertising), Media (Editorial and Audiovisual), Culture (Heritage and Arts, Music, Performing Arts and Cultural Expressions) and Technology (Research and Development, Biotechnology \& Information and Communication Technology).

Although there are different segmentations or approaches, we can highlight the presence of the audiovisual industry in these approaches. According to the mapping of Industry Federation of the State of Rio de Janeiro - FIRJAN (2016), the audiovisual creative industry employed 46,200 people, with an average salary of R 2.805 in the period from 2013 to 2015 in Brazil. In 2017, despite this sector having suffered a drop of $-11.4 \%$ in the number of jobs generated, in 2019 the increased salary went to R \$ 7,863.The state of Paraná, in the media sector (editorial and audiovisual), had 6,230 formal jobs from 2013 to 2015, and it was above the national average in the participation of professionals in the sector until 2017. Thus, the data presented show how much, only a sector that is part of the so-called creative economy that encompasses goods and services that go beyond art, whose main raw material is creativity and intellectual capital, represents in economic terms for Brazil.

However, the audiovisual, as a creative industry, can be seen as a vector of development beyond economic context, but also by social and cultural context, since it can present symbolic value, express art, encourage creativity and cultural diversity through the cinema (Gonçalves \& Santos, 2013). Since then, both the culture and creative industries have played an important role in the (re) creation, and use of urban spaces, which were sometimes appropriate for tourism (Gonçalves, 2008). In Brazil, it was observed that in some investigations that several municipalities encouraged by the increase in tourist demand began to perform the function as film sets for audiovisual productions, specifically cinema.

Assuming that cinema is a system that can influence other segments such as tourism, the city of Garibaldi - RS has been betting on audiovisual as a way to diversify the tourist scene with the circulation of image, and creation of from the perspective of existing products and services (Silveira \& Baptista, 2017). Another Brazilian city was Tiradentes - MG which obtained considerable tourist projection through audiovisual productions that used its architectural ensemble as scenarios for films, soap operas, and miniseries throughout the 1990s/ 
2000s. Similar was observed in the city of Cabeceiras - PB, which accumulates a total of approximately 23 feature films, this city by boosting tourism contributed to the creation of a local market due to the need for infrastructure for film production, such as food and lodging, in addition to leveraging ecotourism and promoting local handicrafts (Nascimento, 2009).

Costa and Perinotto (2013) points out the government of Piauí's state together with the tourism company (Empresa de Turismo do Piauí S/A - PIEMTUR), a tourist company of the 1970s, was assertive in producing the film "Guru das Sete Cidades" (1972) to promote the state through the scenarios composed of places and sights "where through the images made of these, one could have an idea of what Piauí state would offer yesterday, and today, if it arose the interest of visiting the state, making it suitable for the development of tourist activity" (Costa \& Perinotto, 2013, p. 21).

The film "O Quatrilho" (1994), gave rise to a tourist itinerary in Gramado - RS, with the localities like Campestre do Tigre and Tapera, places where the feature film was recorded, the municipality explores the junction of tourism and cinema "associated with agritourism, and the cultural and historical theme of regional colonization presented in the film" (Nascimento, 2009 , p. 59). Parts of the place where the filming took place are preserved as material heritage because its architecture represents influences of the first Italian and German immigrants who arrived in the region. The local community finds in tourism an activity complementary to the main income of agriculture (Nascimento, 2009).

Santos, Alencar and Neves (2018) observed the performance of the creative film industry in the city of Curitiba - PR that the film "Estômago" (2007) contextualized competitive advantages through new attributes associated with gastronomy (the theme of the feature film), and cinema, as influencing elements in the composition of the image of a tourist destination and in promoting the city's identity as creative, in addition to proposing the establishment of new relationships between managers, companies, and sectors that can benefit the city.

These were just some of the Brazilian examples that served to demonstrate the relevance in the use of audiovisual productions, especially cinema as a creative industry that directly or indirectly approaches tourism, and which can be understood as something favorable to local development. Thus, the following theme will present considerations about the city of Castro PR and the film "Os Xeretas" (2001), the object of analysis of this paper. 


\subsection{The film production "Os Xeretas" (2001) and the city of Castro - PR}

Castro's city (Figure 1), according to the estimates of the last demographic census, in 2019, has approximately 71,000 inhabitants. It is in the Campos Gerais region and geographically composes the first and second plateau sines. It is the third-largest city in the state in territorial extension, known as the "Mother City of Paraná". Castro has eight properties listed by the Historical and Artistic Heritage of Paraná, these being the Museu do Tropeiro (Drover Museum), Casa de Sinhara (Sinhara's House), Casa da Praça (Square's House), Casa da Cultura Emília Erichsen (Emília Erichsen House of Culture), Fazenda Capão Alto (Capão Alto Farm), Estação Ferroviária (Train station), and also two houses with commercial functions, located in the Historic Center of the city. On the route that leads to the city, it is possible to visit the Guartelá Canyon, the sixth-largest canyon in the world, located between the municipalities of Castro and Tibagi (Castro City Hall's, 2019).

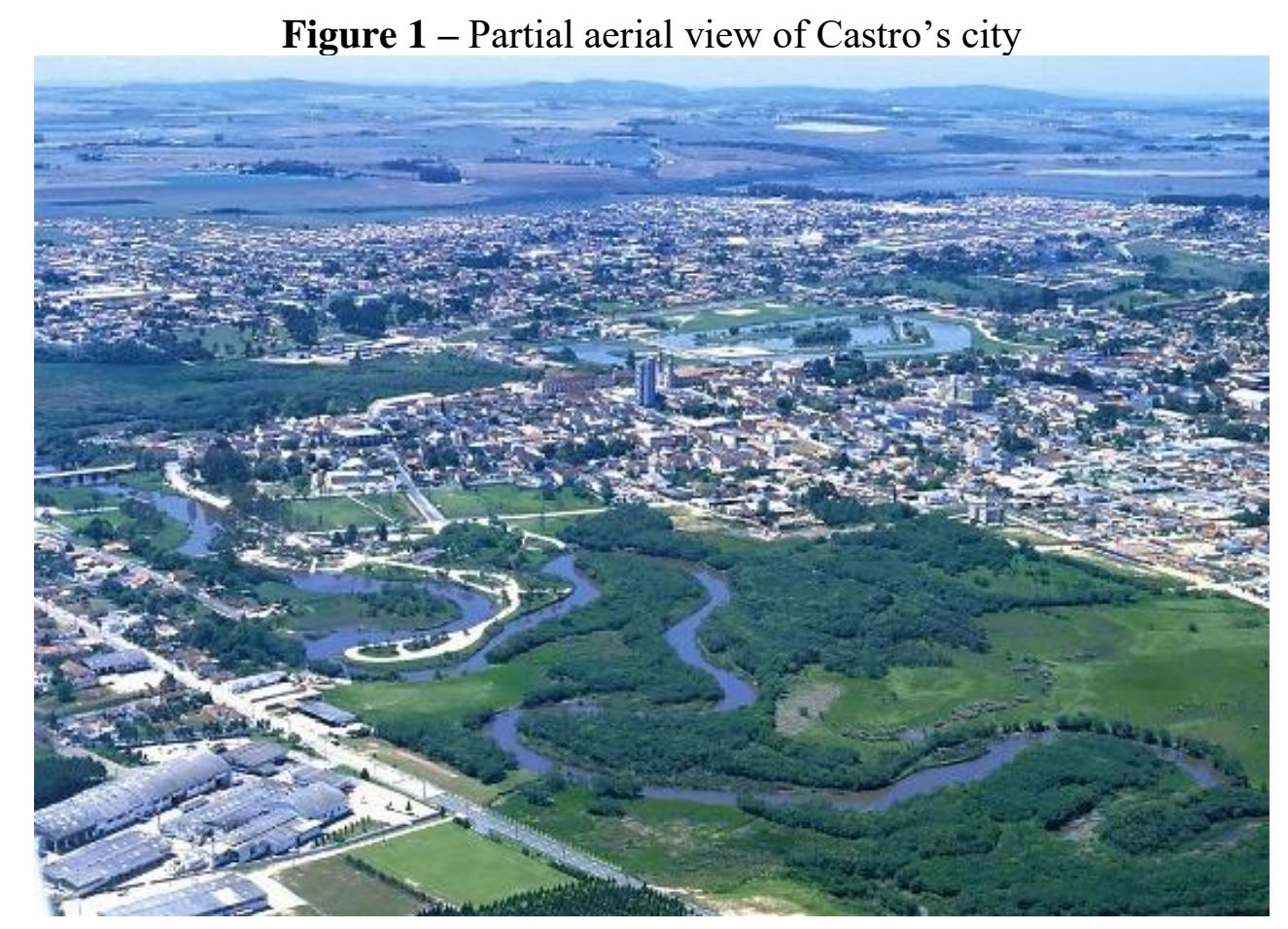

Source: Castro City Hall’s, 2019.

In Castro's economy, it is observed that it is Gross Domestic Product (GDP) has the following distribution: $50 \%$ in the service sector, $28.10 \%$ in agriculture, $14.4 \%$ in the industrial sector, and $7.5 \%$ in taxes. Because of these data, it is possible to notice that the predominant economy of the city is in the service sector, even with agriculture standing out in the position of 23rd in the national GDP ranking. Another data to be considered is the Municipal Human Development Index (MHDI) considered between medium and high, through the variables 
considered among income with 0.704 (high); Longevity with 0.823 (Very high), and Education with 0.600 (medium) (Castro City Hall, 2019).

The main segmentation of tourism in Castro are directed to cultural and gastronomic context due to the presence of immigrant colonies, and parties with typical foods of these colonies (Tramontin \& Gândara, 2010); similarly, the Strategic Plan of Tourism Marketing of Paraná 2016 - 2026 (Strategic Plan of Tourism Marketing of Paraná - PEMTP, 2018), presents the city of Castro as a place for cultural experiences through the Castrolanda's Cultural Center and friendship experience ${ }^{3}$, by the presence of immigrant colonies, a fact that corroborates with the mentioned authors.

The Castro's city was the setting of the feature film "Os Xeretas" (2001), a children's production on magic, portals of time, and mystical symbols. The story of this fiction is about the search for a portal of time and space protected by the Aleph, who in the film are guardians who through a medallion can access the portal. The "xeretas" is the nickname given by the local population to the three friends who get involved to help a time-traveling girl found lost in the city, together they go out in search for the key of this portal, the medallion stolen from the Museum in São Paulo - SP.

The film "Os Xeretas" is a production of Magia Filmes with the participation of TV Cultura, and with the support of the Project by Museum of Image and Sound (MIS), an audiovisual circulation, and dissemination program that aims to promote the formation of audiences, and the circulation of cinema works in the state of São Paulo. The film participated in its world premiere at Montreal's International Children Film Festival; it was also shown at the German Children's Film \& TV; Golden Sparrow Festival; and at the Recife Film Festival, and Brasília Film Festival. After, the film has been participating in local education and film events, such as the cine club of Federal University Grande Dourados (UFGD) ${ }^{4}$, Cinema in the Library Project in Ortigueira city, and the Project MIS (Governo do Estado de São Paulo, 2009).

\footnotetext{
${ }^{3}$ In relation to experiences, the Paraná Plan Tourist 2026 - Pact for an intelligent destination, profiles (personas) for each segment observed in the State of Paraná. Thus, when talking about culture experience and friendship experience, he refers to the data and approach of the Paraná Tourist Plan. The Plan is available online for a better understanding of the theme and its scope: Retrieved April, 2019, from https://goo.gl/i3hykr.

${ }^{4}$ Cine Club UFGD was created in early 2009 by some administrative technical groups and professors of UFGD (Federal University of Grande Dourados) is an extension project, with free screenings and open to the public of national and international films. Retrieved January, 2019, from https://goo.gl/Px8cEc
} 


\section{METHODOLOGY}

To understand the interface between the creative sector in the cinematic perspective reflected in tourism, the qualitative and descriptive path was adopted, in which it combines different research emphases with the needs of the object of study and research design, with a collection of multiple sources of information. Concerning this theme, the qualitative methodology portrays and contextualizes new knowledge, and consequently, the possibility of reflection on sociocultural problems and conceptions of reality (Creswell, 2007; Alves, 2011). First, bibliographic research was carried out on the theme followed by data collection about the film through communication vehicles and documents from the Castro City Hall. On the website of the feature film "Os Xeretas", there are interviews, technical information, and description of the experience during the recordings.

Then, a semi-structured interview was conducted with Silvana Fontana, representative production of Magia Filmes Company, that explained the dynamics to audiovisual set in the city of Castro during the recordings of the film. Mrs. Fontana answered a set of questions formulated according to the methodological principles of Flick (2009) whose thematic direction of the interview directly points to the specific hypotheses and topics associated with the literature Scientific.

Finally, it adhered to the pairing as a strategy of analysis and interpretation of data by the authors Laville and Dionne (1999) to visualize the characteristics of the dynamics between creativity, cinema, and tourism, and to understand their contributions to the city of Castro through the film "Os Xeretas". Data pairing considers the measurable domain of each specific element of data collection, thus verifying the correspondence between a theoretical construction and a phenomenon or study situation through the observation of the object of analysis (Laville \& Dione, 1999).

Through data pairing, three aspects of the creative industries presented by Richards (2011) were identified: market interactions, attributes of association, and authenticity. From these characteristics, it was possible to understand the development of the creative industry, and its articulations between various agents (Santos, Alencar, \& Neves, 2018). Therefore, the interpretation and analysis of the pairing of data from the research originated an operational table of the results that contributed to the achievement of the result. 


\section{ANALYSIS AND DISCUSSION OF RESULTS}

\subsection{The creative economy in Castro - PR}

The development of creativity associated with the field of tourism is a consequence of the nature that touches the activity since when meeting with the service sector needs to deal with competition and work elements that increase the value chain (Pine II \& Gilmore, 1999). Cultural tourism, for example, expanded the offer by working with intangible resources of a symbolic character by adding to the new narratives the heritage of the city, becoming strategically creative (Richards \& Wilson, 2006).

Based on the theoretical framework on creative industries, specifically the audiovisual, and on the film "Os Xeretas", plus the data obtained through methodological procedures, some points were highlighted that interconnect, to understand the contributions that the development of the creative film industry can offer to the city of Castro (Table 1).

Table 1 - Aspects and contributions of "Os Xeretas" (2001) for the city of Castro - PR (pre and postproduction)

\begin{tabular}{|c|c|c|}
\hline $\begin{array}{c}\text { Attributions of film production "Os } \\
\text { Xeretas" }\end{array}$ & Aspects of creative sectors & $\begin{array}{c}\text { Contributions to the city of } \\
\text { Castro - PR }\end{array}$ \\
\hline $\begin{array}{c}\text { Elements of film production (people } \\
\text { involved, equipment, and services). }\end{array}$ & Newmarket interactions. & $\begin{array}{c}\text { Job creation and promotion of } \\
\text { the creative class. }\end{array}$ \\
\hline Use of urban spaces as film sets. & $\begin{array}{c}\text { New attributes associated } \\
\text { with the target. }\end{array}$ & $\begin{array}{c}\text { Combination of tangible and } \\
\text { intangible resources. }\end{array}$ \\
\hline Symbolic elements are linked to the city. & Authenticity. & Competitive advantage. \\
\hline
\end{tabular}

Source: Adapted from Santos, Alencar and Neves, 2018.

- Employments and the local economy:

Florida (2003) points out the presence of the creative class in a place promotes regional economic growth consequently the increase in the concentration of creative capital, marked by the presence of stimuli such as job creation, general economic growth, the formation of businesses involving technology and innovation. This constant stimulus by creative individuals seeks in diversity the opportunity necessary to generate new experiences.

In an interview with Brazilian newspaper Jornal Folha de Londrina (Merten, 2000), the producer Roberto d'Ávila emphasizes the employability of local labor and reforms to repay Castro City Hall's support to produce the film. In the same interview, Roberto d'Ávila comments that there was the intention of developing tourism in the city of Castro, and the film was an element that could contribute to this goal. 
In Castro's city, there was an incitement to the creative audiovisual industry through the movement in the local commerce of the city and the generation of employment. In an interview with Fontana (2017), it was reported that a large part of the film crew was made up of professionals from the region, because in a high-scale production several services are requested, in addition to the workforce of specific professionals, there is the indirect participation of other sectors of local trade.

The production of this film, specifically, had the initiative to indicate to the production
that the purchases were made all in the local trade of Castro, except in case of a
specific product that could not be purchased in the city. After all, part of the film's
budget (which totaled more than 2 million reais) circulated in Castro's trade. Also, the
production company in partnership with SENAR, at the time, held a training course
for professionals for the audiovisual sector. Some of the graduates worked in the
production (Fontana, 2017, p. 1).

The data collected in the interview with Mrs. Fontana (2017), present a total number of 260 people composed of the production, logistics, and actors' teams, and a total of 150 people from the community. The city's support for film production contributed $30 \%$ to the reduction of production expenses. The information cited demonstrates the openness of public and private agencies in the city of Castro with the audiovisual creative industry. Florida (2003) and Cruz (2012) points out one of the essential characteristics for attracting the creative class are tolerant, diverse, and open places for new ideas, the incitement of a social and cultural environment is the central aspect for economic development under the creativity.

Creative production is associated with a dynamic process from the principle that public art can trigger the regeneration of urban spaces, generating multiplier effects on the local economy and increasing the aesthetic value of these places (Richards \& Wilson, 2006; Gonçalves, 2008). As indirect services, Mrs. Fontana (2017) cites the rental of houses, hotels, and pensions for lodging of the staff and the cast. As an indirect service, the interviewee cites supermarkets, pharmacies, restaurants, transportation, stationery, among others, and as a direct service, the hiring of labor to build scenarios, costumes, and technical support such as joiners, painters, seamstresses, secretaries, cooks, department assistants, electricians, photographers, drivers, among many others.

- Heritage revitalization and preservation:

For the production of the film "Os Xeretas", there was the recovery of urban spaces such as the old cinema "Cine Plaza" that was closed for a long time and was totally renovated to be the headquarters of the production, and later was the site of Avant-première. Next to the cinema, other urban spaces were also rebuilt, such as The Central Square of Castro, bars, the club, and the ice cream shop (Merten, 2000). These processes improve the image and stimulate creativity 
with reflections to the urban through temporary installations, community projects, and exhibitions (Gonçalves 2008).

\section{- Social Capital:}

Social capital is the basis of the support of a territory that considers its connections, and social constructs by sharing a way of life and identity in innovative cultural dimensions that allow new connections influenced by creativity in the transformation of these spaces into creative territories (Emmendoerfer \& Ashton, 2014). Kim and Richardson (2003) points out the visual language is a vehicle for transmitting meanings and building familiarity with the place from two components: the exploration of the cognitive, with beliefs and values linked to local physical attributes, and the affective exploration, with the evocation of emotions about the place.

In Castro, there was community involvement with the audiovisual sector through courses, a free exhibition for students from the public-school network of the city, and workshops. "The film was of great impact to the community, because, in addition to the production itself that circulated through the streets, neighborhoods [...], there was still effective interference in local self-esteem" (Fontana, 2017, p. 2).

After the recording of the film "Os Xeretas", the producer of Magia Filmes Homero Camargo, reported the collaboration in future activities in the city that aimed to attract to the site other audiovisual productions that would take advantage of the legacy left by the film such as renovations and permanent constructions. As well as the intention to set up a Scholar Cine, in partnership with the National Trade Service (SENAC) of the city, to conduct film production workshops, and contribute to regional technical training (Tela Viva, 2000). According to Steingraber (2013), the education of a population is associated with growth in the service sector, favored by the creative economy, which is energized by cinema, and this, in turn, corresponds to an industry with economic and social characteristics that directly impact human capital. That is, in Castro's case, the film "Os Xeretas" obtained profitability for the producers, and the local population.

Although the film can be considered as a means of raising awareness about visiting places used as scenarios because of the power of imagination, fantasy, and history that results in associations between the script, the location, and the emotional stimuli. Cinema generates an expectation, and the increase in the tourist flow will be a consequence (Riley \& Van Doren, 1992; Riley, Baker, \& Van Doren, 1998; Beeton, 2010; Connell, 2012). 
According to Guimarães (2009), the film narrative supported such symbolic constructions and identity issues as an element of cultural mediation by giving a vision and meaning to a given context and place. In the film "Os Xeretas" there are no elements of negative representation for the city of Castro that is presented with neutrality when considering aestheticrepresentational models of Brazilian national cinema, different from productions of the New cinema period, and the cinema of the Resumption in Brazil, which "present the excluded and marginalized, as visions of dirt, ugliness, and aggressiveness " (Guimarães, 2009, p. 193). This fact can be considered as a positive point for the city of Castro.

- The legacy:

In the year following the filming of the film "Os Xeretas", Castro received the film production "Sonhos Tropicais", which used part of the structure of both physical and local personnel left by the film "Os Xeretas", was the same team of producers in partnership with director André Sturm (Fontana, 2017). In an interview with the regional newspaper Folha de Londrina (Schwartz, 2007), producer Homero Camargo reports the involvement of Castro's population with the film crew, this relationship encouraged the creation of a cooperative composed of producers, joiners among other services in addition to encouraging courses to put into practice concepts of education, production, and audiovisual dissemination. The Cinema $\&$ Digital Media Cooperative has already produced other documentaries about the culture and history of Paraná.

Fontana (2017) points out the continuity of audiovisual actions in the city of Castro caused numerous advantages such as the construction of a core of cultural training, and qualification, installation of training centers and studios, and other film productions. The city began to have cinema as cultural equipment and agriculture as a socioeconomic activity (Castro City Hall's, 2019).

However, the audiovisual approaches tourism, since the latter has as characteristic innovation, cultural and economic expansion and contributes to the formation of a virtuous cycle between companies, community, government, and educational institutions and by contributing to the strengthening of social capital and value attributes related to services and attractions (Tomazzoni, 2012).

According to Correa-Quezada, Álvarez-García, Río-Rama and Maldonado-Erazo (2018), even with the increased interest in research that relates the contributions of creative industries to the economy of countries and regions, the amount of specialized literature is still insufficient for a broad understanding. What is perceived is that the influence of creative industries for the generation of employment and regional development is demonstrated through 
a close relationship between creativity, development, and economic growth. Compared to the case study on Ecuador, in which mapping of the production chain is presented in which the areas of architecture, crafts, visual arts, audiovisual, dance, design, education, photography, music, computer science, and theater stand out (Correa-Quezada et al., 2018), similar was perceived in the city of Castro during the film production.

Thus, observations, relevance, and knowledge of a phenomenon resulting from the convergence between creativity, cinema, and tourism (Beeton, 2010), whose studies open the way for further investigations into the possible existence of a tourist flow motivated exclusively by film productions as well as the impacts in other contexts to those outlined in this work, are based.

Therefore, the audiovisual is constituted as a creative sector by providing new market interactions through the generation of local employment, and the promotion of classes, attributed to the destination by association from new identities and symbols coming from of this performance whose authenticity may become a competitive advantage (Richards, 2011). Fontana (2017) points out an audiovisual sector is a communication tool that can be used by tourism. As an example she cites that the film "Os Xeretas" generated approximately three million reais in spontaneous media, placed the city of Castro as a subject in the main media of print, television, and digital communications throughout Brazil; left a tangible legacy through the heritage restorations and the built scenarios that were temporarily open for visitation, and the intangible legacy of the imaginary associated with the film.

\section{CONCLUSION}

This work was a reading of how a film production moves a city. It sought to understand what would be the contribution of the audiovisual creative industry to a little Brazilian city; how cinema (film production) attributes new aspects to this a place; what would be the characteristics of the dynamics of cinematographic activities from the perspective of the creative economy, and how they would reflect on tourism.

Among the perceived impacts there was the restoration of the city's cinema, the involvement of the community to assist in production, the facilitation of cultural access mainly in a country like Brazil that does not encourage culture as it should (proven by low investments in cultural resources). So that, if it were not for the film "Os Xeretas" the city would continue in the same molds and rhythms as before. 
The relationship with tourism was and is inevitable since the film production itself already entails a movement of visitors in the city, and in the second instance benefits from activities that help in the preservation of urban heritage. So, the practice of tourism, seen as a factor of development in the areas of culture and creativity, especially when it is a destination outside the commercial circuit São Paulo - Rio de Janeiro, has provided the involvement of people, products, services, and creative environments. In this sense, creative tourism (Richards, 2009), presented itself as an alternative to the demand for experiences, distinguishing or segmenting destinations in the tourist market, involving tourists more actively in activities that go beyond the material aspect of consumption, for example, in Castro's case for the incentive that the creative industry could provide through experiences related to audiovisual productions.

Thus, presenting a film recorded in 2001 in the city of Castro / PR - Brazil, as the main cinematographic production at this location, was intended to show the managers of the tourist trade the importance that the creative industry when associated with the audiovisual context, and effective and continuous management after a film production, can provide opportunities such as free advertising, spontaneous marketing and feedback on social networks and rating platforms.

Given the examples mentioned previously (Bento Gonçalves-RS, Tiradentes-MG, Cabaceiras-PB, Piauí, Gramado-RS, Curitiba-PR, and others), it was noticed that the outcome that the creative economy provided to these locations was not the same as perceived in the city of Castro-PR, over time. While in other cities the productions made before 2001, are still alive in the memory and feed the imagination of residents and visitors; in Castro, the film "Os Xeretas (2001)" showed benefits in the creative economy only at three moments: in pre-production, in production, and just a few years later. The city of Castro has shown no concern in the long run and consequently has not taken advantage of the benefits that the creative industry has provided. Nineteen years after the release of "Os Xeretas" the new generations - national and regional do not know the film, the older generations have already forgotten it, in some cases. Both, the public and private sectors have not shown effective actions to attract national demand and perpetuate the benefits of film production. It is not easy for a city to be chosen to host the recordings of a feature film, and when this occurs, all stakeholders should bear in mind initiatives that aim to maximize this benefit as much as possible.

Thus, this article sought, through creativity, to understand cinema as an element that attributes new aspects to a place. It was observed that concepts related to the creative industries are associated with the city of Castro from the pre-production of the film "Os Xeretas", through 
the development of creative activities, to the individual talent of each component in postproduction at short and medium-term.

It is possible to note that cinema as a creative industry is interesting for the city since the main economic activity in the service sector, as we saw in the data related to GDP. And as a socio-cultural activity, it can be a possible tool to improve the MHDI. These aspects need to be observed and worked on in the long term, to consolidate or extend the maximum benefits achieved.

The constructions, renovations, and recoveries in public spaces the city of Castro made by and for production are associated with the spaces and scenarios of the film that was assembled for a while (as a film set) after the production for the visitation, and that during that time became part of a creative and real environment. The permanent heritage that has been restored induces the feeling of preserving the identity of other decades. The use of local labor and commerce before and during the production of the film, as well as the involvement of the community with the post-production audiovisual sector, demonstrate the creative potential in an environment that has transformed and become conducive to this.

Thus, if cinema proposes an approach to tourism based on the assumption of awareness of places through the image and the symbol that the film associates with the landscape (Riley \& Van Doren, 1992; Riley, Baker, \& Van Doren, 1998), some alternatives will be presented so that the city of Castro can again benefit from cinematographic productions: through the new forms of consumption that converge to the search for experiences accompanied by attempts to (re) adapt to the new (re) readings of the city of Castro, it can also count on cultural and gastronomic devices designed to meet the needs of visitors mainly in search of experiences related to cinema. This article discussed how the theme of the creative industry was able to impact a given space and understood that these impacts, whether positive or negative, do not last forever, so as a suggestion for future research: Find out how long the creative industry can sustain itself in cities with few or many effective actions? At first, we already thought that the chances of a city being able to maintain itself without effective actions are very small, but all factors such as engagement, the audience of film production, and the location of the destination, among others, must be analyzed. On the other side of this point, there may be high investments ineffective actions, but the destination may be difficult to access, geographical language barriers, high prices, among other factors to be considered.

This film, even produced in 2001, implied disruptive actions in all sectors of the city, in a material and immaterial way. Contributed to the visual identity of the destination, with the 
confirmation of a specific tourist sector through the creative industry, which directly and indirectly favored the local economy.

The advantage of a case study, like this, is that it acts as timeless, seeking to fully observe a certain past and present context (defined time and space), that is, the time factor, of a film that was recorded in 2001, but which concerns phenomena that occurred on the site, and impacted the shaping of reality in the city, its residents and visitors to the present day, proving the strength of the creative industry.

Therefore, it is concluded that this research provided the observation, and analysis of a case that can serve as a parameter for other cities since the city of Castro / PR managed to obtain good results only for a while compared to other places that also served as scenery.

\section{ACKNOWLEDGMENTS}

We express gratitude for the esteemed Ph.D./Professor José Manoel Gândara (in memoriam) for all his contributions in life in this research. Rest in peace.

\section{REFERENCES}

Alves, M. L. B. (2011). Reflexões sobre a pesquisa qualitativa aplicada ao turismo. Revista Turismo Em Análise, 22(3), 599.

Beeton, S. (2010). The Advance of Film Tourism. Tourism and Hospitality Planning \& Development, 7(1), 1-6.

Bendassolli, P. F., Wood, T., Kirschbaum, C., Pina, \& Cunha, M. (2009). Indústrias Criativas: Definição, Limites E Possibilidades. RAE - Revista de Administração de Empresas, 49(1), $10-18$.

Campo, M. L., Fraiz Brea, J. A., \& González, M. E. A. (2013). Nuevos Segmentos Turístico Culturales. Una Aproximación Al Comportamiento Del Consumidor Turístico Cinematográfico. Cuadernos de Turismo, 32(32), 259-279.

Campo, L. R., Fraiz Brea, J. A., \& González, E. A. (2014). El turismo cinematográfico como tipología emergente del turismo cultural. PASOS. Revista de Turismo y Patrimonio Cultural, 12(1), 159-171.

Castro City Hall's. (2019). Portal do Cidadão. Retrieved from https://castro.atende.net/

Connell, J. (2012). Film tourism - Evolution, progress and prospects. Tourism Management, 33(5), 1007-1029.

Correa-Quezada, R., Álvarez-García, J., Río-Rama, M., \& Maldonado-Erazo, C. (2018). Role of Creative Industries as a Regional Growth Factor. Sustainability, 10(5), 1649.

Costa, D., Brandão, F., \& Vieira, A. (2018). Turismo Cinematográfico: Uma proposta de valor para a cidade do Porto. Revista Turismo \& Desenvolvimento, 1(27/28), 2157-2170. 
Costa, E. S., \& Perinotto, A. R. C. (2013). "Guru Das Sete Cidades": Cinema E Comunicação Turística Da Região Norte Do Estado Do Piauí - Brasil. Turydes: Revista de Investigación En Turismo y Desarrollo Local, 6(14).

Creswell, J. W. (2007). Projeto de pesquisa métodos qualitativo, quantitativo e misto. (2nd ed.). Artmed.

Cruz, A. R. (2012). Atracção da classe criativa e recursos primários no turismo do Algarve. VII Congresso Português de Sociologia, 7.

Emmendoerfer, M. L., \& Ashton, M. S. G. (2014). Territórios criativos e suas relações com o turismo. Revista Turismo \& Desenvolvimento, 4(21/22), 459-468.

Flick, U. (2009). Qualidade na pesquisa qualitativa: coleção pesquisa qualitativa. (1st ed.). Bookman.

Florida, R. (2003). The rise of the creative class. Basic Books.

Fontana, S. (2017). Semi structured interview. (unpublished).

Furtado, S. (2015). Indústrias Criativas: Festival de Cultura e Gastronomia de Tiradentes/Minas. Pontifícia Universidade Católica - PUC SP.

García Suárez, J. A., \& Pulido Fernández, J. I. (2015). Creacity, una propuesta de índice para medir la creatividad turística. Aplicación en tres destinos urbano- culturales españoles. Revista de Estudios Regionales, 7585(13), 69-108.

Gonçalves, A. R. (2008). As Comunidades Criativas, o Turismo e a Cultura. Revista dos Algarves, 17, 10-17.

Gonçalves, É. de A., \& Santos, F. A. dos. (2013). Economia Da Cultura, Cinema E Desenvolvimento. Revista O Mosaico, 10, 50-67.

Governo do Estado de São Paulo. (2009). Programação. MIS - Museu Da Imagem e Do Som. Recuperado de https://www.mis-sp.org.br/programacao/320/os-xeretas-e-oficina-de-cinemade-animacao

Guimarães, D. (2009). O Filme "Estômago": Comida, diversão e arte. Revista Contracampo, 20, 188-204.

Hartley, J. (2005). Creative industries. In Creative industries. Wiley-Blackwell.

Industry Federation of the State of Rio de Janeiro - FIRJAN. (2016). Diagnósticos e mapeamentos Setoriais: Mapeamento da Indústria Criativa no Brasil.

Justos, G. M. (2015). A Produção Cinematográfica nos Campos Gerais e o uso da Imagem pelo Turismo. Universidade Estadual de Ponta Grossa.

Kim, H., \& Richardson, S. L. (2003). Motion picture impacts on destination images. Annals of Tourism Research, 30(1), 216-237.

Landry, C. (2011). Cidade Criativa: A história de um conceito. In Reis, A. C. F. (Ed.). Cidades Criativas - Perspectivas. Garimpo de soluções. 
Laville, C., \& Dione, J. (1999). A construção do Saber: Manual de metodologia da pesquisa em ciências humanas. Artmed: Editora UFMG.

Merten, L. C. (2000). O dia-a-dia da produção do filme “Os Xeretas" está na Internet. Jornal Folha de Londrina. Recuperado de https://www.folhadelondrina.com.br/folha-2/o-dia-a-diada-producao-do-filme-os-xeretas-esta-na-internet-282217.html

Miguez, P. (2007). Economia criativa: uma discussão preliminar. In G. M. Nussbaumer (Ed.). Teorias \& políticas da cultura: visões multidisciplinares. EDUFBA.

Nascimento, F. M. (2009). Cineturismo. (1st ed.). Aleph.

Pine II, B. J., \& Gilmore, J. H. (1999). The experience economy: work is theatre \& every business a stage. Harvard Business Press.

Reis, A. C. F. (2008). Creative Economy as a development strategy: a view of developing countries. Itaú Cultural.

Richards, G. (2009). Turismo Cultural: Padrões e implicações. Turismo Cultural: Estratégias, Sustentabilidade e Tendências, 25-48.

Richards, G. (2011). Creativity and tourism. Annals of Tourism Research, 38(4), 1225-1253.

Richards, G., \& Wilson, J. (2006). Developing creativity in tourist experiences: A solution to the serial reproduction of culture? Tourism Management, 27(6), 1209-1223.

Riley, R., Baker, D., \& Van Doren, C. S. (1998). Movie induced tourism. Annals of Tourism Research, 25(4), 919-935.

Riley, R. W., \& Van Doren, C. S. (1992). Movies as tourism promotion. Tourism Management, 13(3), 267-274.

Rocha, G. A. P., \& Brusadin, L. B. (2012). Pós-modernidade e convergência cultural: o caso do Cineturismo. Anais do XVII Congresso de Ciências Da Comunicação Na Região Sudeste, Ouro Preto, Minas Gerais, Brasil.

Santos, M. L., Alencar, D. G., \& Neves, S. C. (2018). As indústrias criativas de audiovisual e gastronomia no destino turístico Curitiba: uma análise através do filme Estômago. Marketing \& Tourism Review, 3(1).

Schwartz, W. (2007). O foco geográfico do cineasta em Ventania. Jornal Folha de Londrina. Recuperado de https://www.folhadelondrina.com.br/cidades/o-foco-geografico-do-cineastaem-ventania-601141.html

Silveira, V. P., \& Baptista, M. L. C. (2017). Turismo e cinema na Capital Nacional do Espumante - Garibaldi. Revista Cenário, 5(8), 67-82.

Steingraber, R. (2013). Economia da cultura e da criatividade: uma abordagem da indústria cinematográfica brasileira pelo capital social e cultural. Acta Scientiarum. Human and Social Sciences, 35(2), 175.

Strategic Plan of Tourism Marketing of Paraná - PEMTP. (2018). (unpublished).

Tela Viva. (2000). Scanner: Xeretice. Tela Viva. Retrieved from https://issuu.com/telaviva/docs/pdf_93_ok 
Tomazzoni, E. L. (2008). Dimensão Cultural Do Turismo: Uma Proposta De Análise. Revista de História e Estudos Culturais, 8(3), 1-15.

Tomazzoni, E. L. (2012). Observatório de Turismo e Cultura, integração regional do cluster de turismo e desenvolvimento socioeconômico da Serra Gaúcha. In Beni, M. C. (Ed.).

Turismo planejamento estratégico e capacidade de gestão. (1st ed.). Manole.

Tramontin, R. G. M., \& Gândara, J. M. G. (2010). Producción Y Transformación Territorial: La gastronomía como atractivo turístico. Estudios y Perspectivas En Turismo, 19, 776-791.

FORMAT FOR CITATION OF THIS ARTICLE

ALENCAR, D. G., SANTOS, M. L., \& GUISSONI, R. (2021). Creative economy, cinema and tourism: a study about the movie "Os Xeretas" in the city of Castro/ Paraná - Brazil. Revista de Turismo Contemporâneo, 9(1), 104-125.

https://doi.org/10.21680/2357-8211.2021v9n1ID20709 